\title{
A PHARMACOGNOSTICAL STUDY OF MONSONIA NIVEA DECNE. WEBB. GROWING IN EGYPT
}

Mohamed S. Afifi, Madiha A. Hassan, Zain-EL Abden M. Naeim and Weaam N. Elsayed

Department of Pharmacognosy, Faculty of Pharmacy, University of Mansoura, Egypt

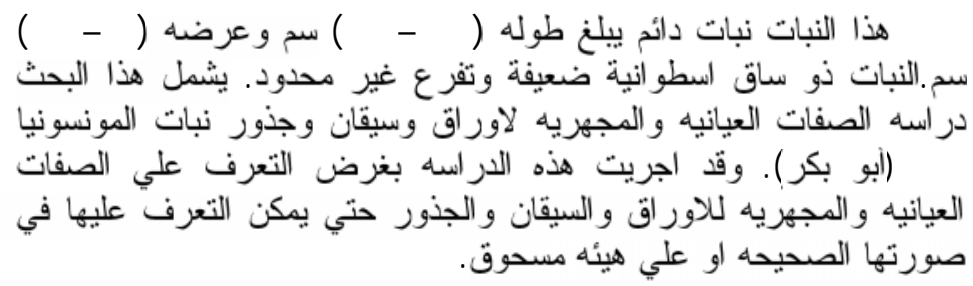

The macro- and micro-morphological characters of the leaves, petioles, stems and roots of Monsonia nivea Decne.Webb. (Family Geraniaceae) have been studied in order to identify them in both entire and powdered forms.

\section{INTRODUCTION}

Monsonia nivea Decne.Webb. is among the Egyptian wild plants belonging to the family Geraniaceae. The plant was reported under the names Dahma, Dahma-a, Qarna, Qarni, Yahaq, Abu bakr, Ghozlaan, El-ghozlaan and Arabic name (أبو بكر) ${ }^{1}$. The name nivea means white snow as the plant is silvery green ${ }^{1}$. Monsonia nivea Decne.Webb. is known as $(\text { (يه) })^{2}$.The plant was used together with other members of the Geraniaceae in bacillary desentery ${ }^{3}$.

Preliminary phytochemical screeninig of the aerial parts of Monsonia nivea Decne. Webb. Was carried out ${ }^{4}$ and revealed the presence of carbohydrates and/or glycosides, flavonoides, saponins, tannins, unsaturated sterols and/or triterpenes ${ }^{4}$.

The anti-oxidant activity, from all compounds isolated from the different extracts of Monsonia nivea Decne.Webb exhibited a definitive free radical scavenging activity, comparable to ascorbic acid. The isolated flavones and flavonols from 
the same plant showed similar results ${ }^{4}$.

The dried methanolic extract of the aerial parts of the plant showed an antimicrobial activity against the Gram +ve bacteria; Staphylococcus aureus. All the tested materials isolated from the plant viz., $\alpha$-amyrin, $\beta$-sitosterol, ursolic acid, methoxy flavone, Apigenin-7-o-glucoside, quercetin-3-o-glucoside and rutin showed an activitiy against E.coli in the following descending order: ursolic acid, dried methanolic extract of the aerial parts, $\beta$-sitosterol, $\alpha$ amyrin then rutin. All the isolated materials previously mentioned showed antifungal activitiy against Candida albicans in the following descending order: ursolic acid, $\beta$ sitosterol, $\alpha$-amyrin, rutin and the dried methanolic extract of the aerial parts ${ }^{4}$.

Concerning the anti-tumor activity ursolic acid showed high anti-tumor effect $^{4}$.

The plant is a perennial herb attaining up to $(25-40) \mathrm{cm}^{1}$ in length and up to $(5-25) \mathrm{cm}$ in diameter. The plant has a weak cylindrical monopodially branched stem. The stem carries simple opposite stipulate leaves. It has short internodes of unequal lengths.

The flowers ${ }^{5}$ are actinomorphic and bracteate and hermaphrodite. Some of the flowers having twowhorled perianth. The calyx usually consists of 5 distinct imbricate sepals. The corolla consists of 5 distinct petals (rarely $8,4,1$, or none). Nectiferous glands are usually present alternating with the petals. The stamens are typically 5-15 in numbers arranged in 1-3 whorls. Sometimes the stamens are reduced to antherless or staminodes. Some of the flowers belonging to the genus Monsonia having stamens united in tridelphous or pentadelphous manner. The anthers are bi-lobed, dehiscing longitudinally. The ovary is superior with 3-5 bilocular carpels. The ovules are anatropous and arranged 1-2 in each locule showing axile placentation. The styles are slender and the stigmas are flat, rarely capitate. The inflorescence is cymose or umbeltype.

The fruit ${ }^{5}$ is a capsule, dehiscing septicidally into 3-5 parts. Each part contains one, two or many seeds. The styles remain or sometimes spirally.

The seed $^{5}$ is albuminous with narrow endosperm and showing an incumbent embryo.

Reviewing the current literature little was found concerning the botanical study of the plant, so, such study was carried out for the available parts of the plant to help in its identification on both entire and powdered forms.

\section{EXPERIMENTAL}

Plant material: The plant material Figure (1) was collected from wild perrenial plants growing in south of Sinai districts (Wadi El-Ghozlan on Sharm Elsheikh/ El Tor road) in April 2001. The plant identity was authenticated by Prof. Dr. M. Nabil Ahmed Khirat EI-hadidi (Prof. of 
Plant Ecology and Flora of Egypt, Department of Botany, Faculty of Sciences, Cairo University).

Several trials for the collection of the flowering plants were carried out but failed due to the scarcity of these plants during the following seasons (2002 to 2005).

\section{Macromorphology}

The Leaf, Figure (2A) is simple, opposite usually arranged in rosettes. It is stipulate (stipules are oblong lanceolate measuring about 2, $\underline{3}, 4$ $\mathrm{mm}$ in length and $0.5, \underline{1}, 1.5 \mathrm{~mm}$ in width) and petiolate with cylindrical long petiole attaining about $1, \underline{3.5}, 4.5$ $\mathrm{cm}$ in length and $0.5 \mathrm{~mm}$ in diameter. The lamina is ovate-oblong in shape, with symmetric base. The lamina measures $1,2.5,3 \mathrm{~cm}$ in length and $0.5, \underline{1.5}, 2 \mathrm{~cm}$ in width. The lamina has a crenate to dentate margin with acute apex and reticulate pinnate venation. It is hairy on the lower surface and glabrous on the upper one. The leaves are dull green in colour being paler grayish green in the lower one. It has a disagreeable odour and a bitter astringent taste.

The stem, Figure (3A) is erect to procumbent, weak and more or less cylindrical in shape. It is monopodially branched, greenish brown in colour when fresh, becoming yellowish brown when dry, with hairy surface. It has short internodes of unequal lengths ranging from 1.5 to $4 \mathrm{~cm}$ in length, bearing opposite leaves. The stem attains 25 to $40 \mathrm{~cm}$ in length and $0.5, \underline{2}, 2.5 \mathrm{~mm}$ in diameter. It breaks with a fibrous fracture, having a disagreeable odour and a slight bitter astringent taste.

The root, Figure (4A) is a tap root bearing several lateral rootlets. It measures about $10, \underline{15}, 20 \mathrm{~cm}$ in length and 5, $\underline{6}, 7 \mathrm{~mm}$ in diameter. Externally, it is reddish-brown to dark-brown in colour, with rough surface due to the exfoliation of bark. It is more or less cylindrical in outline, solid, with a fibrous fracture, having a disagreeable odour and a bitter astringent taste.

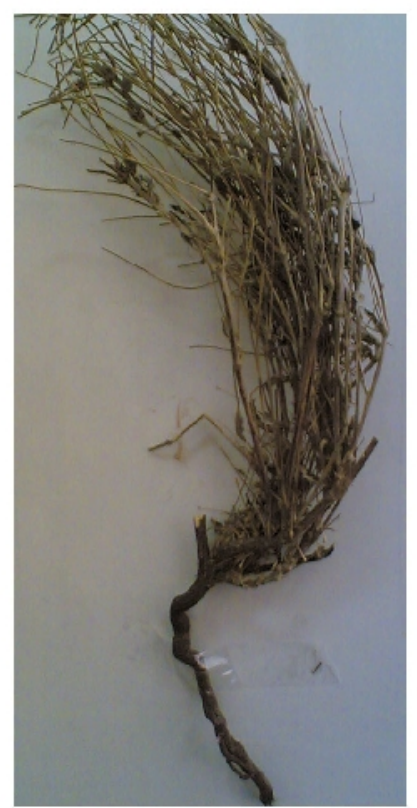

Fig. 1: Photo image of Monsonia nivea Decne. Webb.

\section{Micromorphology}

The leaf: Figures $(2 \mathrm{~B}, 2 \mathrm{C}, 2 \mathrm{D}$ and 2G)

A transverse section in the lamina shows a dorsiventral structure with a 
well-developed single layer of palisade beneath the upper epidermis, occupying about $1 / 2$ of the width of the lamina, and 3 to 4 layers of spongy tissue. The mesophyll cells beneath the palisade show crystal layer containing cluster crystals of calcium oxalate. The palisade tissue is discontinuous on the midrib region. The cortical tissue in the midrib region is parenchymatous beneath the upper epidermis and showing 2-3 layers of collenchyma over the lower epidermis. The midrib shows an open collateral vascular bundle consisting mainly of xylem and phloem surrounded by 2-3 layers of parenchymatous pericycle. The endodermis is formed of single layer of parenchymatous cells. The cortical cells showing idioblasts, some containing clusters of calcium oxalate crystals and others are containing tannin.

The epidermis: The upper epidermis Figures (2D and $2 \mathrm{G}, \mathrm{b}$ ) is formed of polygonal tabular cells with straight thin cellulosic anticlinal walls. They measure about $45,50,55 \mu$ in length, $42, \underline{45}, 50 \mu$ in width and $17,20,21 \mu$ in height. The lower epidermis Figures (1D and $1 \mathrm{~Gb}$ ) consists of smaller, polygonal tabular cells with straight anticlinal walls measuring about $31, \underline{32}, 33$ in length, 32, 33, 34 $\mu$ in width and $14, \underline{15}, 17 \mu$ in height with thin cellulosic walls. Both epidermises are covered with thin smooth cuticle. The lower surface shows numerous long unicellular non glandular trichomes with slight enlarged bases, free from content, thin cellulosic walls, narrow lumena, blunt apices and covered with finely striated cuticle. The glandular hairs have unicellular stalks and unicellular spherical heads. The nonglandular trichomes measure about 160, $\underline{350}$, $500 \mu$ in length and the glandular trichomes measure about $34, \underline{45}, 60 \mu$ in length and $20, \underline{35}, 51 \mu$ in diameter of the head. The stomata are of the anomocytic type present only in the lower surface, nearly spherical in shape measuring about $13, \underline{14}, 15 \mu$ in diameter.

The mesophyll: Figures (2B and 2D). The mesophyll in the lamina region shows a dorsiventral arrangement of the palisade and spongy tissue. The palisade is formed of one layer of cylindrical columnar cells containing chlorophyll and few cluster crystals of calcium oxalate measuring about 13 , $\underline{15}, 20 \mu$ in diameter. The palisade cells measure about $75, \underline{90}, 111 \mu$ in length and 25, $\underline{30}, 37 \mu$ in width. The spongy tissue is formed of thin-walled cellulosic nearly isodiametric parenchymatous cells with narrow intercellular spaces and containing chlorophyll. A cluster crystal of calcium oxalate is found in each spongial cell beneath the palisade forming a crystal layer. The cells of the spongy tissue measure about 25 , $\underline{26}, 30 \mu$ in diameter.

The cortical tissues: Figures (2B and 2C). A transverse section in the midrib region shows the epidermis which is formed of isodiametric cells with straight anticlinal walls showing anomocytic stomata. It is followed by 2-3 layers of polygonal thin-walled 
parenchyma representing the cortical parenchyma. Some of them contain cluster crystals of calcium oxalate that measure about 13, 15, $20 \mu$ in diameter. Some other cortical cells contain spherical tannin masses (stain bluish black with Ferric chloride and measure about 15, 17, $21 \mu$ in diameter). The lower cortical cells consist of 3-5 layers of collenchymatous cells with well distinct intercellular spaces (lacunar collenchyma type) and They measure about 29, $\underline{30}, 38 \mu$ in diameter. The remaining cortical cells are parenchymatous cells measuring about 22 , $33,45 \mu$ in length and $16, \underline{20}, 42 \mu$ in diameter.

The vascular tissue: Figures (2B and $2 \mathrm{C})$. The vascular tissue in the midrib region consists of a large single open collateral vascular bundle, more or less oval, rounded in shape. The pericycle is formed of two to three layers of parenchyma. The cells of the pericycle measure about $16,17,18 \mu$ in diameter. The phloem consists of thin-walled cellulosic parenchyma hardly differentiated into sieve tubes and companion cells, but with no phloem fibres. They measure about 8 , $\underline{9}, 10 \mu$ in diameter. The xylem is formed of lignified xylem vessels of spiral and sclariform type, wood fibres and non lignified xylem parenchyma. The wood fibres are fusiform in shape with slightly thick uneven lignified walls, wide uneven lumena, blunt apices and free from pits. They measure about $700, \underline{800}$, $910 \mu$ in length and about $9,15,22 \mu$ in width.The xylem vessels measure about $16,25,32 \mu$ in diameter and the xylem parenchyma measure about 16 , $\underline{17}, 21 \mu$ in diameter. The cambium is undistinguishable. The lower part of the transverse section of the midrib consists wholly of more or less rounded collenchymatous cells with moderately thick cellulosic walls and distinct intercellular spaces (lacunar type collenchyma). The endodermis is formed of a single layer of parenchyma measuring about $21, \underline{22}$, $23 \mu$ in diameter.

The petiole: Figures (2E and $2 \mathrm{~F}$ )

A transverse section in the petiole is nearly circular to oval in outline. It shows an epidermis with numerous simple unicellular nonglandular trichomes, followed by a narrow chlorenchymatous cortex occupying about $1 / 5$ of the radius of the petiole. The pericycle is formed of a continuous ring of separated batches of fibres above each vascular bundle alternating with batches of sclereids. Six to eight vascular bundles are closely arranged in a wide ring surrounding a wide parenchymatous pith. The vascular bundles are collateral consisting of a narrow phloem and a wide xylem sepatated by a distinct cambium.

The epidermis: Figure (2F). The epidermis consists of polygonal, slightly elongated cells with straight, thin cellulosic walls. It is covered with thick smooth cuticle. The epidermal cells measure about $45, \underline{50 \text {, }}$ $55 \mu$ in length, $42, \underline{46}, 50 \mu$ in width and $29,30,31 \mu$ in height. It is covered with numerous simple 
unicellular nonglandular trichomes with finely striated cuticle. The trichomes measuring about 161, $\underline{180}$, $219 \mu$ in length.

The cortex of the petiole: Figure (2F). The cortex is formed of 3-4 layers of isodiametric very thick-walled nonlignified parenchymatous cells with very few intercellular spaces measuring about 22, 28, $36 \mu$ in diameter. Few cortical cells contain clusters of calcium oxalate measuring about $21, \underline{22}, 23 \mu$ in diameter and very few others contain tannin masses (stain bluish black with Ferric chloride and measure about 22, 23, 24 $\mu$ in diameter). The endodermis is formed of a single layer of polygonal tangentially elongated parenchyma free from contents measuring about $40, \underline{42}, 43 \mu$ in length and $23, \underline{29}, 37$ $\mu$ in width.

The pericycle: Figure (2F). The pericycle consists of a continuous ring of alternating groups of lignified fibres (30-40 above each vascular bundle) and lignified sclereids. The fibres are spindle in shape, with evenly thickened lignified walls, narrow lumena and acute apices. They are free from pits and measure about $950,1000,1200 \mu$ in length and $21,22,23 \mu$ in width. The sclereids are isodiametric moderately thickwalled, pitted and lignified measuring about $29, \underline{32}, 37 \mu$ in diameter.

The phloem: Figure (2F). The phloem consists of thin-walled parenchymatous cells hardly differentiated into sieve tubes and phloem parenchyma but with no phloem fibres. They measure about 25, 26, $27 \mu$ in diameter.

The cambium: Figure (2F). The cambium is formed of one layer of tangentially elongated narrow meristimatic cells. It measures about $25,26,27 \mu$ in length and $21,22,23$ $\mu$ in width.

The xylem: Figure (2F). The xylem is formed of groups of lignified small and large vessels and non lignified wood parenchyma. The vessels are of spiral and sclariform types, measuring about $42,44,48 \mu$ in diameter. The wood fibres are fusiform in shape with slightly thick uneven lignified walls, wide uneven lumena, blunt apices and free from pits. They measure about $750,850,1000 \mu$ in length and about $7, \underline{10}, 15 \mu$ in width. The pith: Figure (2F). The pith occupies about 1/4 diameter of the petiole. It consists of polygonal isodiametric thick walled parenchymatous cells with distinct intercellular spaces, measuring about $21, \underline{30}, 36 \mathrm{u}$ in diameter.

The isolated elements of the leaf Figure $(2 \mathrm{G})$ is characterized microscopically by the following:

1- Polygonal, thin cellulosic upper epidermal cells with smooth cuticle.

2- The lower epidermal cells with smooth cuticle and anomocytic stomata, sometimes showing cicatrices and attached nonglandular trichomes.

3- Simple long unicellular non glandular covering trichomes with slight enlarged bases and 


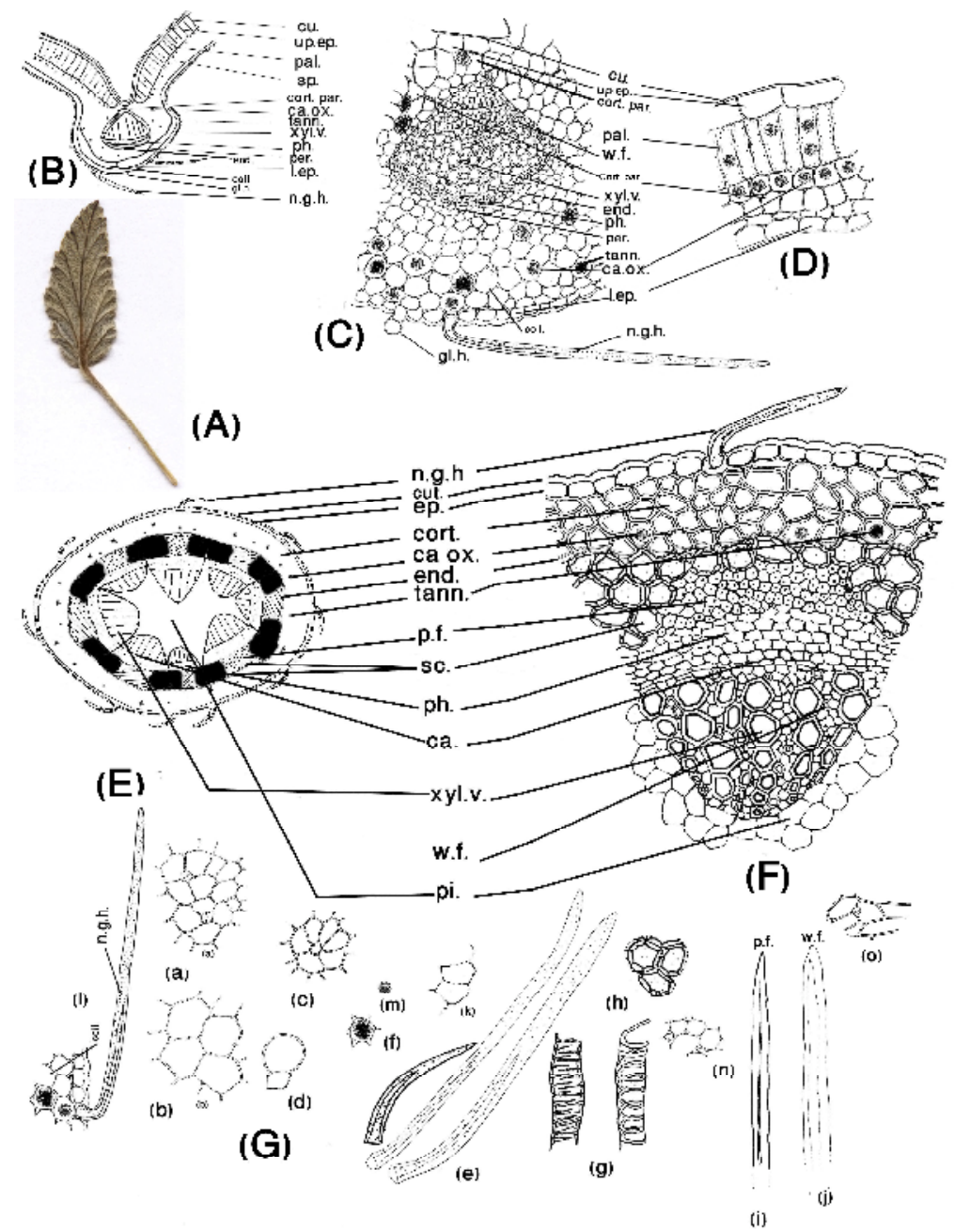

Fig. 2: A, Entire leaf $(X=0.6)$; B, T.cut of the leaf $(X=17)$; C, Detailed T.S. in the midrib region $(X=75)$; $D$, Detailed T.S. in the lamina region $(X=75)$; $\mathrm{E}$, T.cut in the petiole $(X=23) ; F$, Detailed T.S. in the petiole $(X=87) ; G$, Elements of the leaf icluding the petiole; a,Lower epidermis in surface view; b, Upper epidermis in surface view; c, Epidermis with cicatrix in surface view; d, Glandular trichome;e, Nonglandular trichome; f, Cortical cell containing tannin masses; g, Xylem vessels; h, Pericyclic sclereids; I, Pericyclic fibre; j, Wood fibre; $k$, Pith parenchyma; 1 , Lower epidermis and a part of cortical cells showing non-glandular trichome, cluster crystals of calcium oxalate and tannin masses.m, Cluster crystals of calcium oxalate.n- Lower collenchyma with distinct intercellular spaces (lacunar type); o-epidermis of the petiole; ca., cambium; ca.ox., calcium oxalate; coll., collenchyma; cort., cortex; cort. par., cortical parenchyma; cu., cuticle; end., endodermis; gl.h., glandular hair; l.ep., lower epidermis; n.g.h., nonglandular hair; pal., palisade; per., pericycle; p.f., pericyclic fibres; ph., phloem; sp., spongy tissue; tann., tannin; up.ep., upper epidermis; xyl.v., xylem vessel (All $\mathrm{X}=74$ ). 
blunt apices covered with finely striated cuticle.

4- Glandular trichomes with unicellular stalks and unicellular spherical heads.

5- Cluster crystals of calcium oxalate free or enclosed in parenchyma.

6- Sclariform and spiral lignified xylem vessels.

7- Lignified pericyclic fibres of the petiole which are spindle shaped, even thick-walled, narrow lumens, with blunt apices and free from pits.

8- Lignified wood fibres which are fusiform in shape with slightly thick uneven lignified walls, wide uneven lumens, acute apices and free from pits.

9- Isodiametric pitted lignified pericyclic sclereids of the petiole.

10- Pith parenchyma of the petiole.

11- The cortical cells containing tannin masses.

12- Lower collenchyma of the midrib with distinct intercellular spaces (lacunar type collenchyma).

The stem: Figures (3B and $3 \mathrm{C}$ )

A transverse section of the stem is nearly circular to rectangular in outline. It shows an epidermis with numerous nonglandular and glandular trichomes. The epidermis is followed by a narrow chlorenchymatous cortex occupying about $1 / 7$ the radius of stem limited inside by the endodermis. This is followed by the pericycle, which is formed of a continuous ring of separated bands of pericyclic fibres and batches of sclereids. Eleven to twelve vascular bundles are closely arranged in a wide ring surrounding wide parenchymatous pith. Each vascular bundle is collateral consisting of narrow phloem free from fibres and xylem separated by a distinct cambium.

The epidermis: Figures (3B and 3C). The epidermis consists of polygonal to rectangular, slightly elongated cells with straight, thin cellulosic walls. It is covered with thick smooth cuticle. The epidermal cells measure $32, \underline{61}$, $81 \mu$ in length, $17, \underline{42}, 100 \mu$ in width and $11, \underline{22}, 49 \mu$ in height. It is covered with numerous simple unicellular nonglandular trichomes. They have thin cellulosic wall, narrow lumena, blunt apices and covered with finely striated cuticle and measure about $210,227,309 \mu$ in length. and glandular trichomes with unicellular stalks unicellular spherical heads which measure about 73, 97, 99 $\mu$ in length and $48, \underline{49}, 50 \mu$

The cortex: Figures (3B and 3C). The cortex is formed of 3-4 layers of isodiametric very thick-walled chlorenchymatous cells with few intercellular spaces measuring 48, $\underline{150}, 195 \mu$ in diameter. The cortex shows occasional idioblasts containing cluster of calcium oxalate measuring about $48, \underline{49}, 50 \mu$ in diameter and few others contain tannin (stain bluish black with Ferric chloride and measure about $40, \underline{45}, 48$ $\mu$ in diameter). The endodermis is formed of a single layer of polygonal tangentially elongated parenchyma measuring about 50, 60, $70 \mu$ in 
length and $170,172,174 \mu$ in width and is free from content.

The pericycle: Figures (3B and 3C). The pericycle consists of a continuous ring of altenating groups of lignified fibres (30-40 above each vascular bundle) iand groups of isodiametric lignified moderately thick-walled and pitted sclereides. The fibres are spindle in shape, with evenly thickened lignified walls, narrow lumens, acute apices and free from pits. They measure about $950, \underline{1000}$, $1200 \mu$ in length and $48, \underline{49}, 50 \mu$ in width. The irregular to rounded sclereids are lignified and pitted with moderately thickened walls measuring about $97, \underline{170}, 219 \mu$ in diameter.

The phloem: Figures (3B and 3C). The phloem consists of thin-walled parenchymatous cells hardly differentiated into sieve tubes and phloem parenchyma but with no phloem fibres the phloem cells measure about $48, \underline{60}, 85 \mu$ in diameter.

The cambium: Figures (3B and 3C). The cambium is formed of 2 to 3 layers of tangentially elongated thinwalled meristimatic cells. The cambial cells measures about $45, \underline{50}$, $52 \mu$ in length and $121, \underline{122}, 125 \mu$ in diameter.

The xylem: Figures (3B and $3 \mathrm{C}$ ). The xylem is formed of lignified elements including small and large vessels, wood fibres and tracheids. The vessels are of spiral and sclariform types, measuring about $48, \underline{80}, 121 \mu$ in diameter. The wood fibres are fusiform in shape with slightly unevenly thickened lignified walls, with wide uneven lumena, acute apices and free from pits. They measure about $750,850,1000 \mu$ in length and about 51, 53, $55 \mu$ in width. The tracheids are fusiform to rectangular with lignified pitted walls measuring about $162,300,365 \mu$ in length and $74, \underline{76}, 80 \mu$ in diameter.

The pith: Figures (3B and $3 \mathrm{C}$ ). The pith occupies about $1 / 3$ of the diameter of the stem. It consists of isodiametric thick-walled parenchymatous cells with distinct intercellular spaces, measuring about 73, $\underline{90}, 121 \mathrm{u}$ in diameter.

The isolated elements of the stem Figure (3D) is characterized microscopically by the following:

1- Thick cellulosic epidermal cells showing anomocytic stomata and cicatrices.

2- Simple unicellular nonglandular trichomes with slight enlarged bases thin cellulosic walls, narrow lumens, blunt apices and covered with finely striated cuticle.

3- Glandular trichomes with unicellular stalks and unicellular spherical heads.

4- Pericyclic fibres which are spindle in shape, with evenly thickened lignified walls, narrow lumens, blunt apices and free from pits

5- Wood fibres which are fusiform in shape with slightly thick unevenly lignified walls, wide uneven lumens and acute apices. 


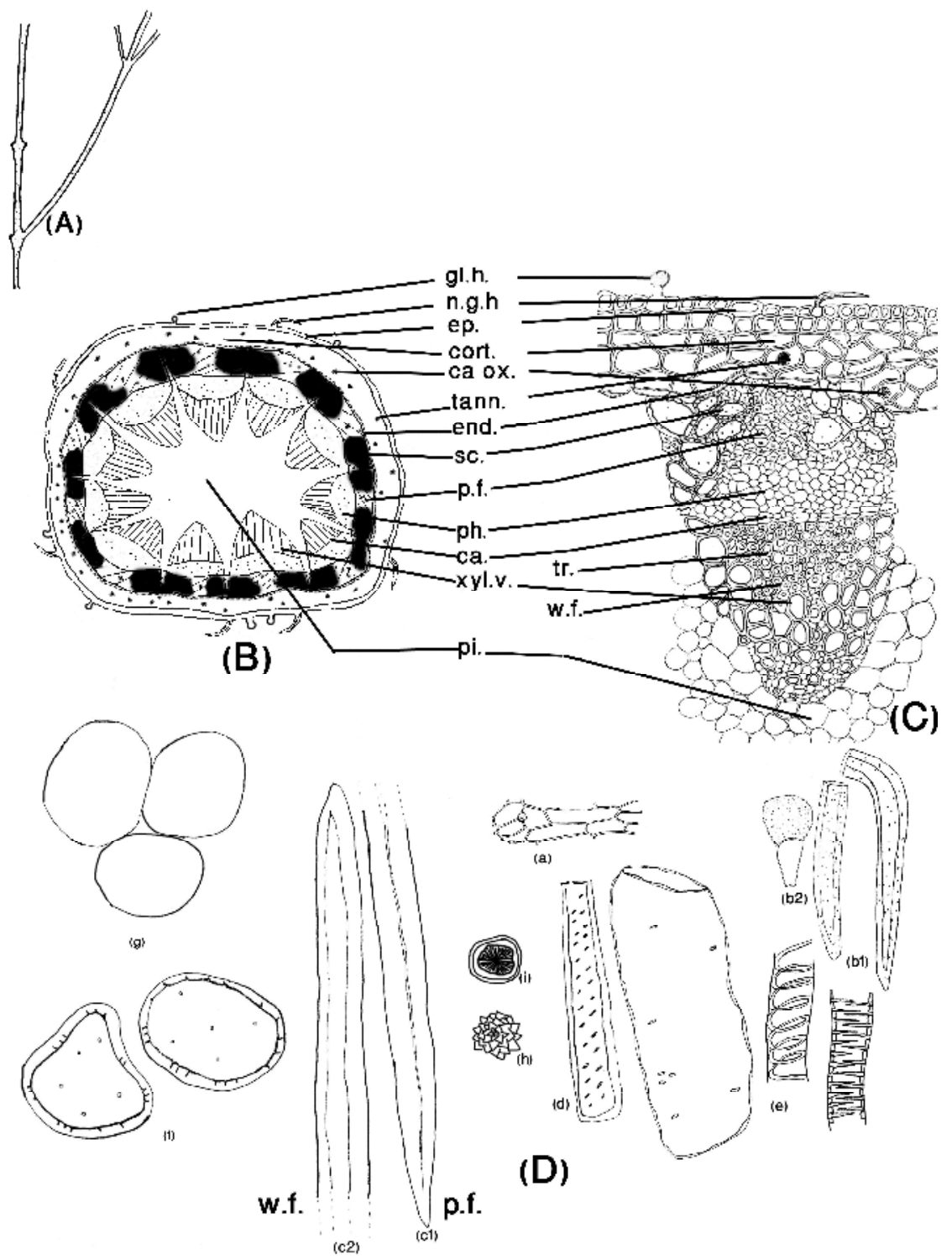

Fig. 3: A, Entire stem $(X=0.8)$; B, T.cut of the stem $(X=0.9)$; , Detailed T.S. in the stem $(X=$ 32); D, Elements of the stem; a; Epidermal cells in surface view; b1, nonglandular trichomes; b2, glandular trichomes; c1, Pericylic fibre; c2- Wood fibre; D, Tracheids; e, Spiral xylem vessels; f, Sclereids of the pericycle; g, Pith parenchyma; h, Cluster crystals of calcium oxalate; i, Cortical cell containing tannin masses. ca.ox., calcium oxalate; ca.,cambium; cort., cortex; end., endodermis; ep., epidermis; gl.h., glandular hair; n.g.h., nonglandular hair p.f., pericyclic fibres; ph., phloem; pi., pith; sc., sclereids; tann., tannin; tr., tracheid; w.f., wood fibre; xyl.v., xylem vessel (all X=97). 
6- Pitted lignified fusiform rectangular tracheids.

7- Spiral and sclariform lignified xylem vessels.

8- Isodiametric lignified pitted pericyclic sclereids.

9- Pith parenchyma which is free from contents.

10- Cluster crystals of calcium oxalate.

11- The cortical cells containing tannin masses, which are stained bluish black with Ferric chloride.

The root: Figures (4B and 4C)

A transverse section in the root is circular in outline. It shows a welldefined cork (phellem) with some exfoliations, followed by three layers of cork cambium (phellogen) and then several layers of secondary cortex (phelloderm). The endodermis and pericycle are indistinct and the main bulk of the root is formed of secondary cortex, secondary phloem and secondary xylem. The cortex is wide formed of 21-25 layers of parenchymatous cells constituting about $1 / 2$ of the section, the outer layers of cortex are formed of large, tangentially elongated cells with thin cellulosic walls containing numerous minute simple or compound starch granules which are oval to round in shape with centric point, cleft or slitlike hilum and an ill-defined striations. The cortical cells contain hydrolysable tannin in the form of masses, which is a common constituent in the family Geraniaceae $^{6}$, staining bluish black with ferric chloride. Some cortical cells also contain few clusters of calcium oxalate $(116, \underline{125}, 158 \mu$ in diameter). The inner cells of the cortex are isodiametric in shape with thin cellulosic walls and contain starch granules. The cortex is followed by a narrow phloem and a wide zone of xylem constituting about $1 / 3$ of the section separated by a very narrow cambium. The primary xylem is arranged in a triarch structure.

The cork (phellem): Figures (4B and 4C). A transverse section in the root shows 12-14 layers of tangentially elongated, polygonal to tubular cells, radially arranged, suberized (stained red with Suddan III) and are containing reddish brown pigment (tannoid in nature). They measure about $140,180,218 \mu$ in length, 109 , $\underline{110}, 180 \mu$ in width and $145, \underline{150}$, $155 \mu$ in height.

The cork cambium (phellogen): Figures (4B and 4C). The cork cambium is formed of 2-3 layers of tangentially elongated cells measuring about $135, \underline{140}, 142 \mu$ in length and $155,156,157 \mu$ in width.

The cortex: Figures (4B and $4 \mathrm{C}$ ). It is a secondary cortex formed of 21-25 layers of cells. The outer cells of cortex are large, tangentially elongated subrectangular to polygonal in shape with thin cellulosic walls, containing yellow to orange pigment which is tannoid in nature (stain bluish black with Ferric chloride bluish black) ${ }^{6}$. Some cortical cells contain few cluster of calcium oxalate measuring about $116, \underline{125}, 158 \mu$ in diameter. They measure about 312 , 
$\underline{320}, 340 \mu$ in length and 233,420 , $622 \mu$ in width. They also contain minute which are simple or compound (3-7 granules) starch granules which are oval to round in shape with centric point, cleft or slitlike hilum and ill-defined striations. The starch granule measures about $38,50,77 \mu$ in diameter. The inner cells of the secondary cortex are polygonal nearly isodiametric in shape with thin cellulosic walls and contain the same starch granules. They are smaller in size measuring about $116, \underline{180}, 233 \mu$ in diameter.

The phloem: Figures (4B and 4C). The phloem consists of 7-9 layers of thin-walled polygonal nearly isodiametric parenchymatous cells hardly differentiated into sieve tubes and phloem parenchyma but with no phloem fibres. They measure about $60, \underline{65}, 70 \mu$ in length and $116, \underline{150}$, $194 \mu$ in diameter. The cambium is formed of a single layer of tangentially elongated cells measuring about $65, \underline{66}, 67 \mu$ in length and 111 , $112,113 \mu$ in width.

The xylem: Figures (4B and $4 \mathrm{C})$. The xylem is with triarch arrangement. It consists of lignified elements including small and large vessels and wood fibres and non-lignified wood parenchyma. The vessels are of scalariform and pitted types, measuring about $116, \underline{200}, 272 \mu$ in diameter. The wood fibres are with pitted thick walls and fusiform in shape with slightly thick uneven lignified pitted walls, narrow uneven lumens and blunt apices and are measuring about $960, \underline{1100}, 1200 \mu$ in length $58, \underline{59}, 60 \mu$ in diameter. The wood parenchyma are isodiametric to polygonal in shape with thin cellulosic non lignified walls measuring about 58, $\underline{59}, 60 \mu$ in diameter.

The medullary rays: Figures (4B and $4 \mathrm{C})$. The medullary rays are radiating from the center of the section and traversing the xylem. They are biseriate to multiseriate (2 to 3 cells).The cells are radially elongated, formed of thin walled parenchyma measuring about $70, \underline{75}, 80 \mu$ in length, $58, \underline{80}, 97 \mu$ in width and 116 , $\underline{140}, 155 \mu$ in height.

The isolated elements of the root Figure (4D) is characterized microscopically by the presence of the following:

1- The cork in surface view showing thick-walled suberized polygonal cells with reddish brown contents.

2- Starch granules which are oval to rounded in shape with centric point, slit-like or cleft hilum and faint striations.

3- Sclariform lignified xylem vessels.

4- Wood fibres which are fusiform in shape with slightly thick uneven lignified pitted walls, wide uneven lumens and acute apices.

5- Medullary rays showing elongated thin-walled parenchymatous cells free from contents.

6- Parenchyma of the cortex containing starch granules and tannin.

7- Calcium oxalate free or in parenchyma. 


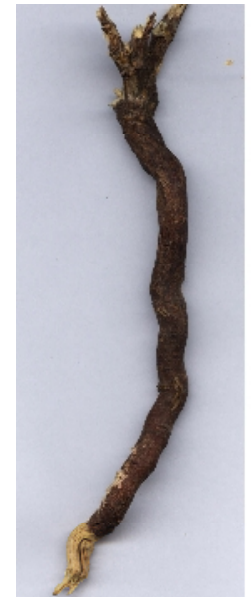

(A)

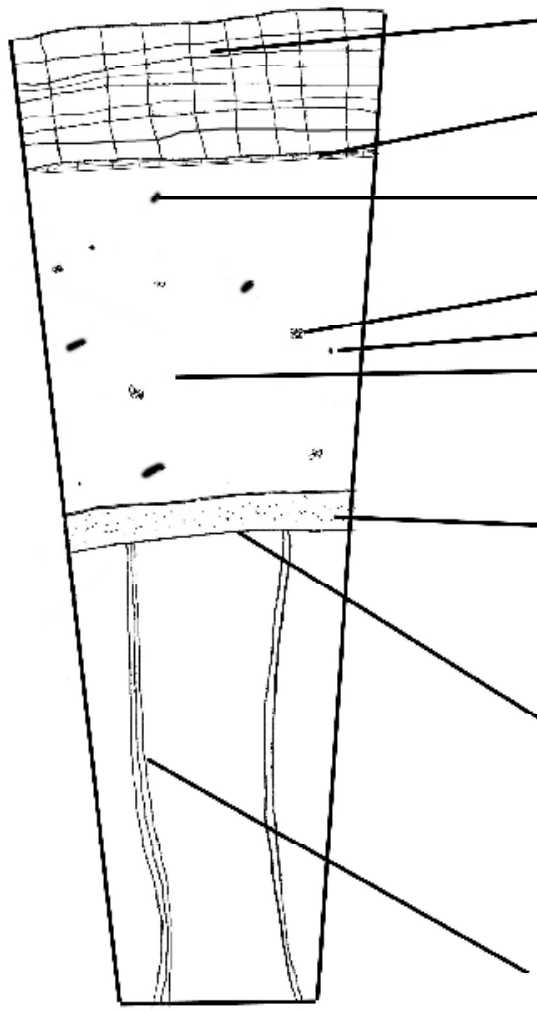

(B)

cor.

co.ca.

tann.

st.

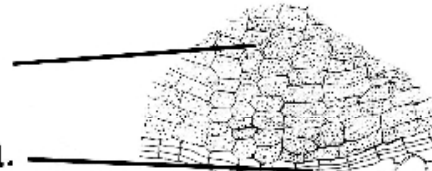

ca ox.

cort.

ca.

ph.

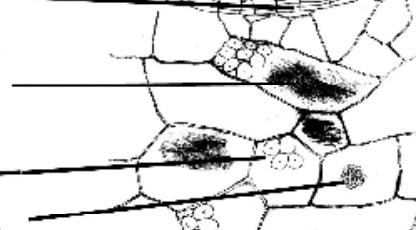

xyl.v

w.f.

m.r.
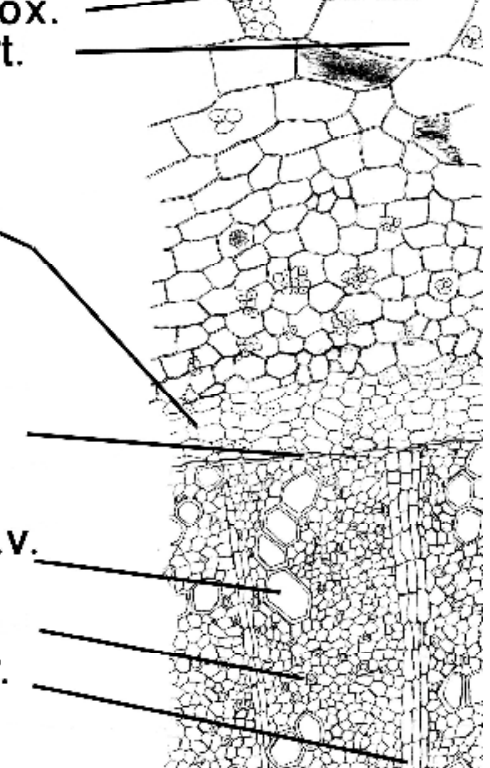

(C)

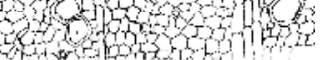

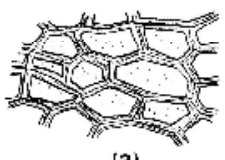

(a)

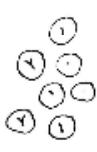

(b)

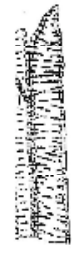

(c)

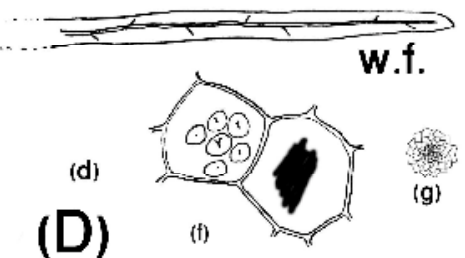

Fig. 4: A, Entire root $(X=0.9)$; B, T.cut of the root $(X=16)$; , Detailed T.S. in the root $(X=$ 24); D, Elements of the root; a, Cork cells in surface view; b, Starch granules; c- Xylem vessels; d, Wood fibres; e, Medullary ray parenchyma; f, Parenchyma containing starch and tannin masses; g, Cluster crystals of calcium oxalate; ca.ox., calcium oxalate; ca., cambium; co.ca., cork cambium; cor., cork; cort., cortex; m.r., medullary rays; ph., phloem; st., starch; tann., tannin; w.f., wood fibre; xyl.v., xylem vessel (all X= 29). 


\section{RESULTS AND DISCUSSTON}

Both macro and microscopical characters of Monsonia nivea Decne.Webb. complies with those published in the literature dealing with the macro and microscopical characters of plants belonging to the genus Monsonia ${ }^{7-10}$. The following points are the most important:

- The presence of rannunculaceous (anomocytic) type of stomata.

- The occurrence of glandular trichomes with unicellular stalks and unicellular spherical heads and non glandular trichomes with slight enlarged bases, thin cellulosic walls, narrow lumena, blunt apices and covered with finely striated cuticle.

- The presence of a broad pericycle in the stem showing a continueous ring of fibre caps above each vascular bundle separated by groups of isodimetric sclereids.

- The pith of the stem is soft and formed of simple parenchyma free from contents.

- The presence of cluster crystals of calcium oxalate, starch and hydrolysable tannins.

- The presence of lignified fibres around the vessels.

- The lignification of xylem vessels are of spiral and scalariform types.

The main histological differences of Monsonia nivea Decne.Webb. than those reported ${ }^{7}$ about the other family members are:-

\section{1- The leaf}

- The absence of uniseriate nonglandular trichomes.
- The absence of the glandular trichomes with uniseriate stalk and unicellular head which is present in Erodium, Geranium, Pelargonium, Viviana, Wendtia and other Monsonia species.

- The absence of glandular shaggy trichome, which is present in Bibersteinia.

- The absence of glandular leaf teeth, which is present in Geranium robertianum $\mathrm{L}$.

- The absence of papillosed epidermal cells, which is present in Monsonia heliotropoides Boiss.

- The stomata of Monsonia nivea Decne.Webb. are abundant only on the lower surface of the leaf but in other plants are present in both surfaces as in Pelargonium coronopifolium Jacq.

- The presence of lower lacunar collenchyma in the midrib of the leaf of Monsonia nivea Decne.Webb.

- The dorsiventral arrangement of the lamina of the leaf in contrast to Monsonia heliotropoides Boiss. and Erodium glaucophyllum Ait.

- The presence of a crystal layer of cluster crystals of calcium oxalate beneath the palisade cells of the lamina of the leaf in Monsonia nivea Decne.Webb. which was not detected in any of the family members.

- The presence of cluster crystal of calcium oxalate in Monsonia nivea Decne.Webb. in contrast to other members which contain other forms of calcium oxalate as, styloids in Rhyncotheca, spherocrystalline 
masses in other Monsonia and Erodium species and short raws of cells containing cluster crystals of calcium oxalate as in Wendtia.

\section{2- The stem}

- The vascular bundles of Monsonia nivea Decne.Webb. are close to each other in contrast to some other members.

- The pith of the stem of Monsonia nivea Decne.Webb. is solid in contrast to some other members which have hollow pith.

- The fibres of the stem of Monsonia nivea Decne.Webb. are free from pits. While in Balbisia, the fibres contain bordered pits and are septate.

\section{3- The root}

- The absence of fatty acids in the tissue of the root.

- The characteristic triarch xylem arrangement of the primary xylem of the root of Monsonia nivea Decne.Webb.

\section{REFERENCES}

1- V. Tackholm, "Students Flora of Egypt", 2 ${ }^{\text {nd }}$ Ed., published by Cairo University, Cairo, 1974, pp. 282-285.
2- A. Issa Bey, Imprimerie Nationnie, Le Caire, 56 (1930).

3- Y. Y. Zhang, S. H. Li and Z. Tian, Yao Xue Xue Bao, 30, 46 (1995). (Through The American Chemical Society (ACS) databases, copyright 2001).

4- M. S. Afifi, M. A. Hassan, Z. M. Naeim and W. N. E. Ebrahim, Mans. J. Pharm. Sci. (in press).

5- G. H. M. Lawrence, "Taxonomy of Vascular Plants", Second Indian Reprint Oxford \& IBH Publishing co.Calcutta Bombay, New Delhi, 1969, pp.551, 676.

6- R. D. Gibbs, "Chemotaxonomy of Flowering Plants", Vol. III, 1974, pp.1337, 1746.

7- C. R. Metcalfe and L. Chalk, "Anatomy of the Dicotyledons", Vol. I, The Clarendon Press, Oxford, 1950, pp. 292, 954.

8- L. Boulus, "Flora of Egypt" Checklist, Al Hadara Publishing, Cairo, Egypt, 1995, pp. 11, 244.

9- L. Benson, "Plant Classification", Oxford and IBH Publishing Co., 1957, pp. 164, 221.

10- L. Boulus, "Medicinal plants of North Africa", Reference Publication Inc., 1983, p. 68. 